Jurnal MAKSIPRENEUR, Vol. II, No. 1, Hal 69-84

\title{
MEDIASI KEPUASAN KERJA DAN STRES KERJA PADA HUBUNGAN ANTARA SELF-EFFICACY DAN KINERJA PENJUAL JASA ASURANSI
}

\author{
Eny Sulistyowati dan Susi Widjajani \\ Fakultas Ekonomi Universitas Proklamasi 45 Yogyakarta
}

\begin{abstract}
The purpose of this research is to examine the relationship between selfefficacy and job performance; job satisfaction and job stress as a mediating variable. This research also investigates the impact of job satisfaction on job performance and job stress on job performance. Variables in this research were measured with a survey of 109 insurances salespersons in Yogyakarta and Semarang. Path Analysis were used to examine the effects of self-efficacy and job performance, job satisfaction on job performance, and job stress on job performance.

Results showed that the relationship showed that self-efficacy significantly related to job satisfaction and performance, but no significant relationship existed with job stress. It also showed that job satisfaction partially mediated the relationship between self-efficacy and job performance. In addition, this research found that job stress not mediated the relationship between self-efficacy and job performance. There is no significant relationship existed between job stress and job performance but this research showed that job satisfaction significantly related to job performance.
\end{abstract}

Keywords: Self-efficacy, Job Satisfaction, job Stress, Job performance.

\section{PENDAHULUAN}

Self efficacy (efikasi diri) merupakan tingkat keyakinan seseorang mengenai kemampuannya menyelesaikan suatu pekerjaan yang akan memengaruhi tujuan, usaha yang dikeluarkan dalam menyelesaikan pekerjaan, tingkat kesulitan pekerjaan yang ditoleransi untuk dikerjakan, kinerja dan pilihan-pilihan aktivitas seseorang. Persepsi seseorang mengenai self efficacy dipengaruhi oleh kepribadian, motivasi dan pekerjaan itu sendiri. Tingkat self efficacy seseorang dapat berubah karena proses pembelajaran, pengalaman diri sendiri dan orang lain serta umpan balik (Gist dan Mitchell, 1992). 
Proses self efficacy memengaruhi fungsi manusia bukan hanya secara langsung, tetapi juga mempunyai pengaruh tidak langsung terhadap faktor lain. Secara langsung, proses self efficacy mulai sebelum individu memilih pilihan mereka dan mengawali usaha mereka. Orang cenderung mempertimbangkan, mengevaluasi, dan mengintegrasikan informasi mengenai kapabilitas yang dirasakan (Brown,et all.,2001).

Dengan kata lain, selfefficacy secara langsung memengaruhi pemilihan perilaku (misalnya keputusann dibuat berdasar bagaimana efikasi yang dirasakan seseorang terhadap pilihannya); usaha motivasi (misalnya orang yang ber- self efficacy tinggi akan mencoba berusaha lebih keras melakukan tugas dari pada yang ber- self efficacy rendah); daya tahan (misalnya orang dengan self efficacy tinggi akan bertahan jika menghadapi kegagalan); pola pemikiran fasilitatif (penilaian efikasi memengaruhi perkataan pada diri sendiri); daya tahan terhadap stres (misalnya orang dengan self efficacy rendah cenderung akan mengalami stres jika mereka kalah dan gagal) (Bandura,1997).

Self efficacy merupakan konstruk motivasi yang penting. Self efficacy sebagai tingkat keyakinan seseorang mengenai kemampuannya menyelesaikan suatu pekerjaan akan mempengaruhi tujuan, usaha yang dikeluarkan dalam menyelesaikan pekerjaan, tingkat kesulitan pekerjaan yang ditoleransi untuk dikerjakan, kinerja dan pilihan-pilihan aktivitas seseorang. Persepsi seseorang mengenai self efficacy dipengaruhi oleh kepribadian, motivasi dan pekerjaan itu sendiri. Tingkat self efficacy seseorang dapat berubah karena proses pembelajaran, pengalaman diri sendiri dan orang lain serta umpan balik (Gist dan Mitchell, 1992).

Efikasi diri juga memainkan peranan vital dalam menentukan kinerja manusia lainnya seperti aspirasi tujuan, insentif hasil, dan kesempatan yang dirasakan terhadap suatu proyek. Apapun tingkat tujuan yang dipilih, seberapa banyak usaha yang dikeluarkan untuk mencapai tujuan tertentu, dan bagaimana reaksi/ketahanan seseorang saat menghadapi masalah dalam proses pencapaian tujuan sangat dipengaruhi oleh self efficacy. Orang berefikasi tinggi berfokus pada peluang yang layak dikejar dan melihat rintangan sebagai hal yang dapat diatasi. Melalui kecerdasan dan daya tahan, mereka mencari cara untuk mengendalikan, bahkan dalam lingkungan dengan peluang terbatas dan banyak hambatan.

Dampak langsung self efficacy pada fungsi manusia sejalan dengan individu berkinerja tinggi. Mungkin profil individu manusia berkinerja tinggi dalam sebuah pekerjaan tertentu adalah orang yang mempunyai self efficacy tinggiyangsungguh-sungguhmelakukan pekerjaannya;memberikan usaha maksimal untuk menyelesaikan tugas; tahan menghadapi rintangan/ frustasi/kemunduran; memiliki pikiran dan perkataan yang positif; dan tahan terhadap stres dan kekalahan. 
Self efficacy yang tinggi membuat karyawan lebih aktif bekerja, berupaya keras, mampu mengatasi situasi kerja yang sulit dan semakin kreatif dalam menyelesaikan pekerjaan (Kreitner dan Kinicki, 2004). Self efficacy juga akan berdampak pada kepuasan kerja, kinerja dan stress kerja karena dengan self efficacy yang tinggi, karyawan akan semakin puas dalam bekerja, mampu mencapai kinerja yang terbaik serta mampu mengatasi stress kerja yang dihadapi di lingkungan pekerjaan.

Hasil riset terdahulu menjelaskan bahwa self efficacy memengaruhi kinerja, kepuasan dan stress kerja. Hasil penelitian Wang dan Netemeyer (2002) menjelaskan bahwa self efficacy mempengaruhi kinerja para tenaga penjual dan proses belajar secara signifikan mempengaruhi self efficacy tenaga penjual. Engko (2006) menemukan hubungan positif self efficacy dengan kinerja individu. Cohrs et al. (2006) juga menemukan hubungan positif antara selfefficacy dengan kepuasan kerja, sementara Gist dan Mitchell (1992) menyatakan ada hubungan negatif antara self efficacy dengan stress individu.

Dari banyak hasil kerja (work outcomes) yang muncul dari selfefficacy, penelitian ini hanya fokus pada kinerja, kepuasan kerja dan stress kerja. Hal ini disebabkan karena ketiga hasil kerja ini memiliki pengaruh penting pada sejumlah variabel lain. Kepuasan kerja dipilih karena memiliki pengaruh penting pada kinerja, ketidakhadiran, organizational citizenship behavior, perputaran karyawan, dan counterproductive behavior (Denton dan Kleiman, 2001). Stress kerja dimunculkan sebagai work outcomes karena stress memberi pengaruh negatif bagi karyawan dan perusahaan, seperti burnout, kecemasan, penurunan kinerja, peningkatan biaya pengobatan kesehatan karyawan (stress memunculkan banyak penyakit fisik dan psikis karyawan), dan perpindahan kerja (Elsass dan Veiga, 1997). Kinerja juga dimunculkan dalam salah satu work outcomes karena kinerja perusahaan ditentukan oleh kinerja-kinerja individu di dalamnya.

Ketiga hasil kerja ini juga saling berhubungan satu dengan yang lain. Kepuasan kerja akan berpengaruh pada kinerja karyawan (Petty et al., 1984). Karyawan yang puas adalah pekerja yang efektif dan berkinerja baik. Kemudian, stress kerja berpengaruh pada kinerja (Narayanan et al.,1999). Stress kerja mempengaruhi kondisi fisik dan perilaku karyawan sehingga cenderung menurunkan kinerja karyawan. Untuk itu tujuan dari penelitian ini adalah untuk mengetahui hubungan antara Self-efficacy dengan kinerja yang dimediasi oleh kepuasan kerja dan stres kerja, serta hubungan parsial antar masing-masing variabel. 


\section{TINJAUAN PUSTAKA DAN HIPOTESIS}

\subsection{Self-Eficacy Dan Kepuasan Kerja}

Penelitian Cohrs et al. (2006) menemukan bahwa self efficacy secara positif berhubungan dengan kepuasan kerja. Menurut Bandura (1997) individu dengan selfefficacy tinggi akan memiliki kepuasan kerja yang tinggi karena mereka merasa berkompeten dan mampu menyelesaikan pekerjaan sehingga pekerjaan menjadi sesuatu yang menyenangkan. Berdasarkan pemaparan ini, maka hipotesis yang disusun adalah sebagai berikut:

Hipotesis 1 : Self-efficacy berpengaruh positif pada kepuasan kerja

\subsection{Self-efficacy Dan Stres Kerja}

Penelitian Wang dan Netemeyer (2002) yang menemukan hubungan positif otonomi kerja dengan self efficacy. Bandura (1997) menyatakan bahwa individu dengan self efficacy tinggi akan mampu mengatasi sumber stress dalam pekerjaan secara efektif. Berdasarkan uraian ini maka dapat dirumuskan hipotesis sebagai berikut:

Hipotesis 2 : Self-efficacy berpengaruh negatif pada stres kerja

\subsection{Self-efficacy Dan Kinerja}

Self-efficacy yang tinggi memiliki hubungan yang kuat dan sangat prediktif dengan kinerja tinggi (Bandura,97). Rata-rata terdapat $72 \%$ probabilitas karyawan dengan efikasi diri tinggi pada tugas tertentu akan memiliki kinerja lebih baik dari pada yang memiliki efikasi diri rendah. Secara khusus ditemukan bahwa semakin kompleks tugas, semakin rendah dampak efikasi diri pada kinerja, meskipun tetap signifikan. Efikasi diri juga memiliki dampak yang lebih besar pada studi laboratorium dari pada di lapangan. Berdasar hal tersebut, maka hipotesis dirumuskan sebagai berikut:

Hipotesis 3 : Self-efficacy berpengaruh positif pada kinerja

\subsection{Kepuasan Kerja dan Kinerja}

Salah satu isu yang kontroversial mengenai hubungan kepuasan kerja dan kinerja adalah pola hubungan kedua variabel tersebut. Setidaknya ada tiga pola hubungan yang mungkin terjadi antara kepuasan kerja dan kinerja (Gibson et al, 2004). 1). Kepuasan kerja mempengaruhi kinerja. Dengan sudut pandang ini diyakini bahwa pekerja yang puas adalah pekerja yang efektif dan memiliki kinerja yang lebih baik. 2). Kinerja mempengaruhi kepuasan kerja. Pola hubungan ini menjelaskan bahwa karyawan yang lebih produktif dan memiliki kinerja yang baik akan memiliki tingkat kepuasan yang tinggi, 3). Kepuasan kerja dan kinerja berhubungan timbal balik. Penjelasan untuk pola hubungan ini adalah bahwa hubungan kepuasan kerja dan kinerja dimediasi faktor-faktor lain seperti pemberdayaan, dan 
persepsi keadilan.

Meta analisis yang dilakukan Petty et al. (1984) menemukan bahwa hubungan kepuasan kerja dan kinerja lebih konsisten dan memiliki korelasi yang lebih besar (korelasi $=0,31$ ). Hasil ini juga didukung dengan temuan Engko (2006) yang menjelaskan bahwa kepuasan kerja memiliki hubungan positif dengan kinerja dengan koefisien path sebesar 0,252. Oleh karena itu, dalam penelitian ini, peneliti mengembangkan hipotesis sebagai berikut:

Hipotesis 4: Kepuasan kerja berpengaruh positif pada kinerja

\subsection{Stress Kerja dan Kinerja}

Stress kerja merupakan salah satu fokus pemahaman dari organisasi karena memiliki peranan penting dalam membentuk dan mempengaruhi sikap karyawan, seperti komitmen organisasional, kepuasan kerja dan kinerja (Sager, 1994). Stress juga dapat mengarah pada penyakit fisik, seperti depresi, serangan jantung, sakit kepala (Eckles, 1987 dalam Moncrief et al. 1997). Narayanan et al. (1999) melakukan penelitian tentang stress kerja dengan membandingkan jenis pekerjaan, seperti admisi, akademisi (professor) dan tenaga penjual. Hasil penelitiannya menjelaskan bahwa konflik interpersonal, beban pekerjaan yang melewati batas, dan membuangbuang waktu menjadi sumber stress yang muncul di tiga pekerjaan tersebut. Namun ada sumber stress khusus yang muncul di tiap pekerjaan tersebut. Kurang kendali akan tugas dan work overload menjadi sumber stress utama bagi para admisi sementara konflik interpersonal menjadi sumber stress utama bagi para tenaga penjual dan akademisi. Dapat dikatakan bahwa stress kerja muncul di tiap pekerjaan dan berdampak pada kinerja individu, kelompok dan organisasi. Semakin tinggi stress yang dialami karyawan maka akan berdampak negatif pada kinerjanya. Berdasarkan penjelasan tersebut, dirumuskan hipotesis sebagai berikut:

Hipotesis 5: Stress kerja berpengaruh negatif pada kinerja

\subsection{Mediasi Kepuasan Kerja Dan Stres Kerja pada Hubungan Antara Self-efficacy dengan Kinerja}

Sejumlah penelitian menemukan bahwa kepuasan kerja memediasi hubungan antara self-efficacy dan kinerja. Seperti dalam penelitian Santi (2007), menemukan bahwa nilai hubungan antara kepuasan kerja dan kinerja lebih tinggi dibandingkan dengan nilai hubungan antara self-efficacy dengan kepuasan kerja. Demikian pula dengan studi yang dilakukan oleh Reni (2008) mengemukakan bahwa stres kerja memediasi hubungan antara self-efficacy dengan kinerja. Berdasarkan penjelasan tersebut, dirumuskan hipotesis sebagai berikut:

Hipotesis 6: Kepuasan kerja memediasi hubungan antara Self-efficacy dengan kinerja 
Hipotesis 7: Stres kerja memediasi hubungan antara Self-efficacy dengan kinerja

Berdasar teori dan hipotesis yang sudah disusun di atas, maka model penelitian ini dapat dilihat pada gambar 1 di bawah ini:

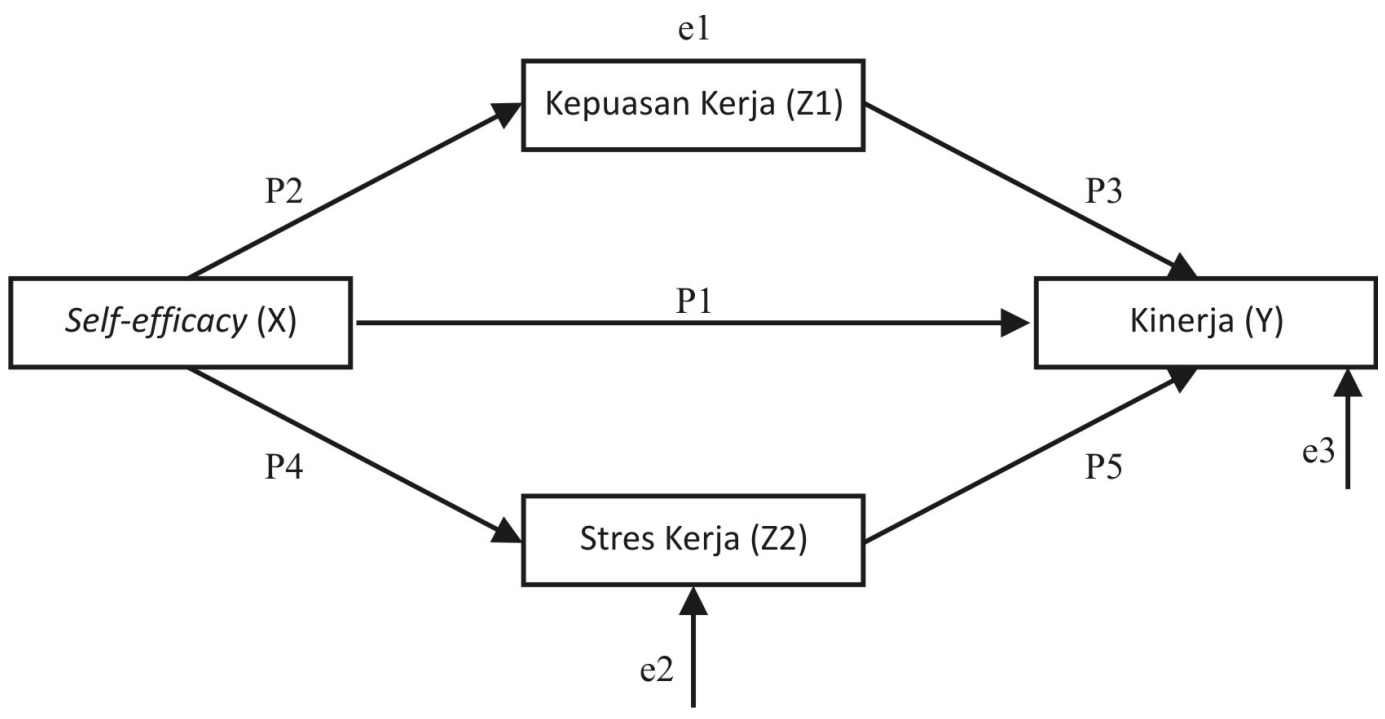

Gambar 1

Model Penelitian

\section{METODE PENELITIAN}

\subsection{Populasi Dan Sampel}

Penelitian ini menggunakan metode survei untuk mengumpulkan data yang diolah. Populasinya adalah tenaga penjual jasa asuransi. Sampel dari penelitian ini adalah tenaga penjual jasa asuransi di Wilayah Kota Yogyakarta dan Semarang. Dari 120 buah kuesioner tersebut ada 110 kuesioner yang berhasil dikumpulkan. Dengan demikian tingkat respon dalam penelitian ini adalah 91,67\%. Dari 110 kuesioner yang kembali, 1 diantaranya tidak layak untuk diolah (rusak), sehingga hanya ada 109 buah kuesioner yang dapat digunakan untuk analisis selanjutnya. Dari 109 data responden yang diolah 60 responden berasal dari Kota Yogyakarta dan 49 responden berasal dari Semarang.

\subsection{Karakteristik Responden}

Secara umum, mayoritas responden adalah wanita $(75,2 \%)$ dengan ratarata umur antara $31-40$ tahun $(48,6 \%)$. Pendidikan responden mayoritas adalah lulusan SMA sebanyak 45,9\%. Dari 109 orang responden yang sudah menikah sebanyak 92 orang. Pengalaman kerja responden sebagai tenaga penjual $>8$ tahun $(47,7 \%)$, dan telah bekerja di perusahaan tersebut selama $>5$ tahun $(52,3 \%)$. 


\subsection{Statistik Deskriptif dan Korelasi antar Konstruk}

Analisis dilakukan pada 24 butir pertanyaan yang telah memenuhi syarat untuk diolah lebih lanjut. Pengolahan statistik deskriptif meliputi rata-rata (mean), standar deviasi dan korelasi. Tabel 1 menunjukkan hasil deskriptif statistik dan korelasi antar konstruk, sebagai berikut:

Tabel. 1

Statistik Deskriptif Data

\begin{tabular}{|l|r|r|r|r|}
\hline \multirow{2}{*}{ Variabel } & \multicolumn{4}{c|}{ Koefisien Korelasi } \\
\cline { 2 - 5 } & \multicolumn{1}{c|}{ SE } & \multicolumn{1}{c|}{ KK } & \multicolumn{1}{c|}{ SK } & \multicolumn{1}{c|}{ K } \\
\hline Self-efficacy (SE) & 1 & $0,308\left(^{* *}\right)$ & 0,095 & $0,349\left(^{* *}\right)$ \\
\hline Kepuasan Kerja (KK) & & 1 & $0,219\left(^{*}\right)$ & $0,388\left(^{* *}\right)$ \\
\hline Stres Kerja (SK) & & & 1 & 0,051 \\
\hline Kinerja (K) & & & & 1 \\
\hline Mean & 5,4839 & 5,1321 & 4,9109 & 4,7317 \\
\hline Std. Deviation & 0,98147 & 0,86119 & 1,14447 & 0,79072 \\
\hline Minimum & 2,00 & 3,60 & 1,43 & 2,75 \\
\hline Maximum & 7,00 & 7,00 & 7,00 & 6,13 \\
\hline
\end{tabular}

** Correlation is significant at the 0.01 level (2-tailed).

* Correlation is significant at the 0.05 level (2-tailed).

Sumber: Output SPSS 13.0 Statistik Deskriptif \& Koefisien korelasi

Hasil pengolahan data (tabel 1) menunjukkan bahwa nilai rata-rata untuk jawaban Self-efficacy adalah 5,4839 dan standar deviasi 0,98147. Hal ini mengindikasikan bahwa responden memiliki tingkat Self-efficacy kerja yang tinggi dengan variasi jawaban yang rendah. Rata-rata jawaban untuk Kepuasan Kerja adalah 5,1321 dan standar deviasi 0,86119, artinya responden memiliki Kepuasan Kerja yang cukup tinggi dengan variasi jawaban yang rendah. Nilai rata-rata untuk stres kerja lebih rendah dari self efficacy dan kepuasan kerja, yaitu 4,9109 dengan standar deviasi tertinggi, yaitu 1,14447. Hasil ini menjelaskan bahwa secara umum responden tidak mempersepsikan adanya stress dalam bekerja sekalipun variasi jawaban responden sangat tinggi. Terakhir, nilai rata-rata kinerja menjadi yang terendah, yaitu 4,7317 dengan standar deviasi 0,79072. Artinya bahwa rata-rata kinerja responden adalah marginal dengan variasi jawaban yang rendah.

Korelasi antar kepuasan kerja dan kinerja menunjukkan korelasi yang tertinggi dibandingkan korelasi konstruk yang lain. Korelasi kepuasan kerja dan kinerja adalah 0.388 (signifikan pada level $\alpha=0,01$ ). Korelasi antara self efficacy dan kinerja juga signifikan dengan nilai $r=0.349$. Selain itu self efficacy 
juga berkorelasi dengan kepuasan kerja dengan nilai $r=0,308$. Korelasi antara Kepuasan kerja dengan stres kerja terjadi pada level signifikan o,o5, yaitu dengan nilai $\mathrm{r}=0,219$. Sementara itu ditemukan juga korelasi yang tidak signifikan antar konstruk, yaitu self efficacy dengan stress kerja dan stres kerja dengan kinerja. Hasil ini menunjukkan bahwa konstruk stress kerja tidak berkorelasi dengan konstruk yang lain. Ini mungkin terjadi karena dalam responden tidak memiliki tingkat stress yang tinggi. Hal ini terlihat dari nilai rata-rata pada stress kerja yang rendah.

\subsection{Teknik Analisis Data}

Penelitian ini bertujuan untuk membuktikan dan menganalisis pengaruh variabel eksogen terhadap variabel endogen. Variabel eksogen adalah Selfefficacy $(X)$, sedangkan variabel endogen adalah kinerja. Variabel kepuasan kerja dan stress kerja digunakan sebagai variabel endogen mediasi. Selanjutnya untuk mengetahui pengaruh langsung dan tidak langsung antar variabel-variabel tersebut digunakan Path Analysis (Analisis Jalur). Dan dengan menggunakan Triming Theory dapat diketahui kesesuaian model akhirnya.

\section{HASIL PENGUJIAN PATH ANALYSIS}

Metode analisis data yang digunakan dalam penelitian ini adalah Path Analysis (Analisis Jalur) dengan Metode OLS (Ordinary Least Square). Analisis jalur merupakan perluasan dari analisis regresi yang digunakan untuk menerangkan akibat langsung dan tidak langsung seperangkat variabel, sebagai variabel penyebab terhadap seperangkat variabel lain yg merupakan variabel akibat. Tabel 2 berikut ini merupakan hasil perhitungan Regresi Linier Model Jalur dengan metode OLS (Ordinary Least Square) berdasar model yang telah disusun :

Tabel 2

Hasil Regresi Linier Model Jalur Metode OLS

\begin{tabular}{|c|c|c|c|c|c|c|c|c|c|}
\hline \multirow{2}{*}{ Variabel } & \multicolumn{3}{|c|}{ Kepuasan Kerja } & \multicolumn{3}{|c|}{ Stres Kerja } & \multicolumn{3}{|c|}{ Kinerja } \\
\hline & $\beta$ & $t$ & $\mathbf{P}$ & $\beta$ & $\mathbf{t}$ & $\mathbf{P}$ & $\beta$ & $\mathbf{t}$ & $\mathbf{P}$ \\
\hline Self-efficacy & 0,308 & 3,351 & 0,001 & 0,095 & 0,987 & 0,326 & 0,255 & 2,799 & 0,006 \\
\hline Kepuasan Kerja & & & & & & & 0,319 & 3,428 & 0,001 \\
\hline Stres Kerja & & & & & & & $-0,043$ & $-0,486$ & 0,628 \\
\hline $\mathrm{R}^{2}$ & & & 0,095 & & & 0,009 & & & 0,211 \\
\hline Adjusted $\mathrm{R}^{2}$ & & & 0,087 & & & 0,000 & & & 0,188 \\
\hline $\mathrm{F}$ & & & 11,228 & & & 0,974 & & & 9,343 \\
\hline
\end{tabular}

Sumber: Hasil Olah Data SPSS 13.0 Path Analysis 
Berdasarkan hasil perhitungan dengan menggunakan program statistik komputer SPSS for Windows Release 13.00 pada tabel 2 di atas, nilai standardized beta Self-efficacy sebesar 0,308 dan signifikan pada 0,001 yang berarti Self-efficacy mempengaruhi Kepuasan Kerja. Nilai koefisien standardized beta 0,308 merupakan nilai path atau jalur p2. Dengan demikian berarti hipotesis 1 terbukti. Selanjutnya nilai standardized beta Self-efficacy menunjukkan angka 0,095 dan signifikan pada angka 0,326, yang berarti Self-efficacy tidak mempengaruhi stres kerja. Nilai koefisien standardized beta 0,095 merupakan nilai path atau jalur p4. Sehingga dapat disimpulkan bahwa hipotesis 2 tidak terbukti.

Pada hasil olah data SPSS 13.0 secara bersamaan nilai standardized beta Self-efficacy 0,255, Kepuasan kerja 0,319, dan stres kerja -0,043. Masingmasing variabel menunjukkan signifikansinya sebesar: Self-efficacy yaitu 0,006, Kepuasan kerja 0,001, dan stres kerja 0,628. Hal ini berarti bahwa terdapat hubungan antara Self-efficacy dan kinerja secara langsung, yang berarti pula hipotesis 3 terbukti. Demikian juga untuk Kepuasan Kerja memiliki hubungan secara langsung dengan Kinerja, yang berarti pula hipotesis 4 terbukti. Nilai standardized beta Self-efficacy 0,255 merupakan nilai jalur path p1 dan nilai standardized beta Kepuasan Kerja sebesar 0,319 merupakan nilai jalur path p3. Sedangkan stres kerja tingkat signifikansi menunjukkan angka 0,628. Hal ini berarti bahwa tidak terdapat hubungan antara stres kerja terhadap kinerja secara langsung. Berarti pula bahwa hipotesis 5 tidak terbukti. Nilai standardized beta stres kerja sebesar $-0,043$ merupakan nilai jalur path p5.

Hasil analisis jalur menunjukkan bahwa Self-efficacy dapat berpengaruh langsung ke Kinerja dan dapat juga berpengaruh tidak langsung yaitu dari Self-efficacy ke Kepuasan Kerja (sebagai variabel mediating) lalu ke Kinerja. Besaran pengaruh langsung adalah 0,255 sedangkan besarnya pengaruh tidak langsung harus dihitung dengan mengalikan koefisien tidak langsungnya yaitu $(0,308) \times(0,319)=0,098$. Oleh karena koefisien hubungan langsung lebih besar dari koefisien hubungan tidak langsung, maka dapat dikatakan bahwa hubungan yang sebenarnya adalah langsung. Hal ini menunjukkan bahwa hipotesis 6 tidak terbukti.

Self-efficacy dari hasil perhitungan tidak memiliki hubungan secara langsung dengan Stres Kerja. Dengan demikian otomatis stress kerja tidak dapat memediasi hubungan antara Self-efficacy dengan Kinerja. Hal ini berarti bahwa hipotesis 7 tidak terbukti. 
Berdasarkan hasil perhitungan, maka dapat digambarkan model jalur penelitian sebagai berikut:

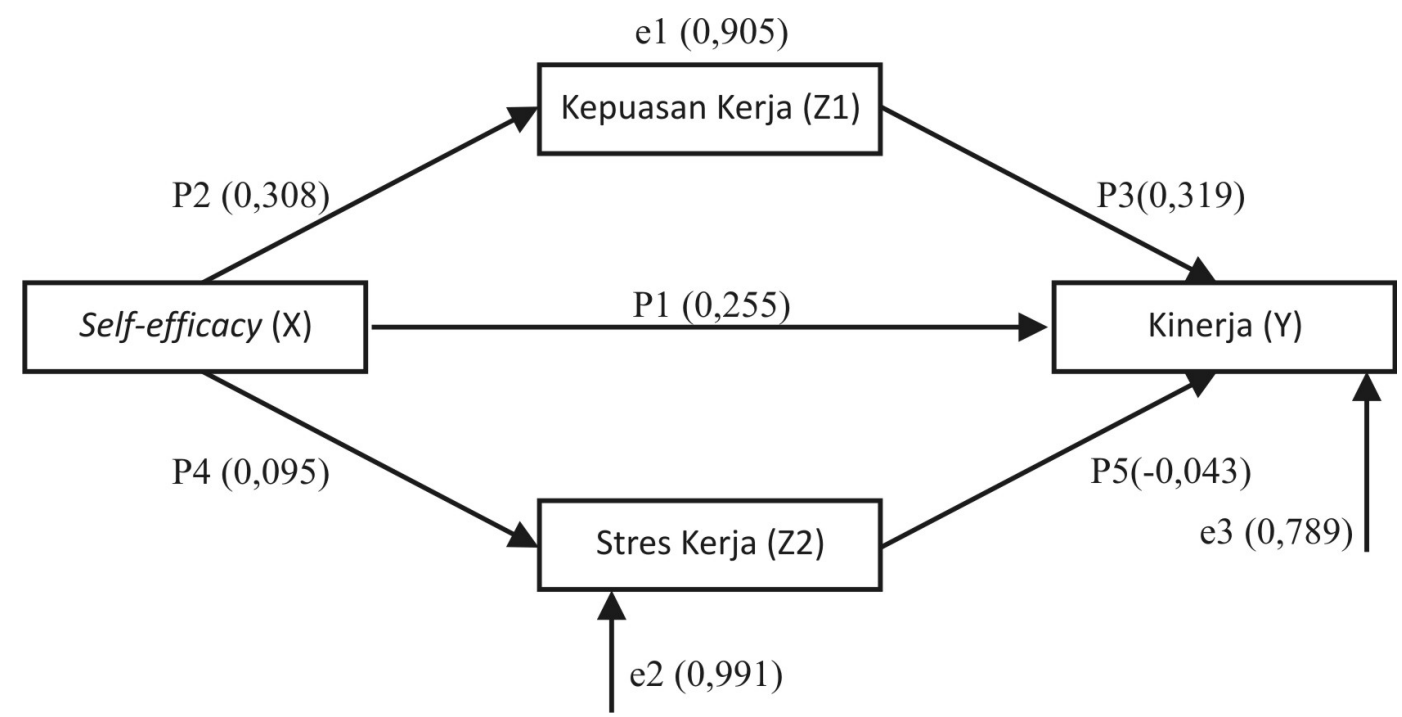

\section{Gambar 2}

\section{Model Hasil Penelitian}

Dalam analisis diagram Jalur (Path Analysis), langkah terakhir yang dilakukan yaitu menghilangkan jalur-jalur yang nonsignifikan (Triming Theory), sehingga diperoleh model yang didukung (konfirmasi) oleh data empirik sebagai berikut:

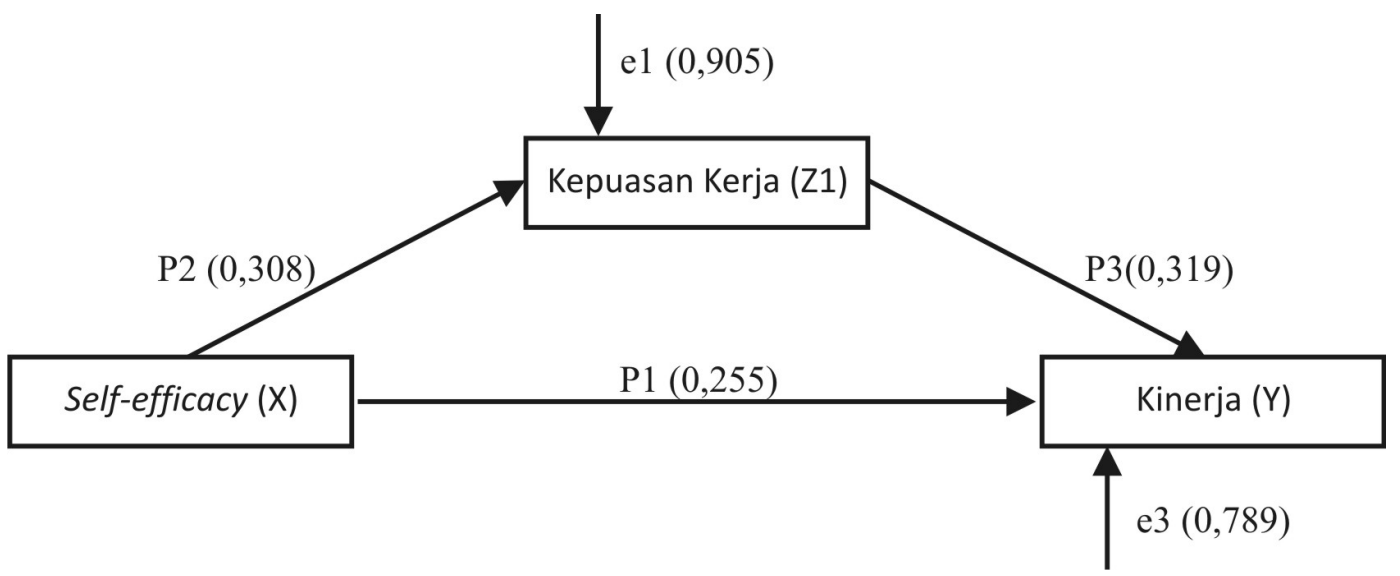

Gambar 3

Model Hasil Penelitian Berdasar Triming Theory 


\section{PEMBAHASAN}

Penelitian ini bertujuan untuk menguji pengaruh self-efficacy dan kinerja, dimana kepuasan kerja dan stres kerja sebagai variabel pemediasi. Penelitian ini dilakukan pada 109 orang tenaga penjual dari penyedia jasa asuransi di Kota Yogyakarta dan Semarang. Hasil pengujian dengan menggunakan Path Analisys. Hasil pengujian hipotesis menunjukkan bahwa ada tiga hipotesis yang terbukti (H1, H3, H4) dan empat hipotesis yang tidak terbukti ( $\mathrm{H} 2, \mathrm{H} 5, \mathrm{H} 6, \mathrm{H} 7)$.

Hipotesis 1 terbukti bahwa self-efficacy berpengaruh positif pada kepuasan kerja. Hal ini mengindikasikan bahwa semakin tinggi self-efficacy yang ada pada tenaga penjual jasa suransi akan meningkatkan kepuasan kerjanya. Hal ini juga terbukti dari gambaran deskriptif data sebelumnya (tabel 1) yang memaparkan bahwa rata-rata responden memiliki selfefficacy dan kepuasan kerja yang tinggi. Hasil ini mendukung penelitian yang dilakukan Cohrs et al. (2006) yang menemukan bahwa dengan self efficacy yang tinggi, karyawan akan semakin puas dalam bekerja. Individu yang mempunyai self efficacy tinggi akan sungguh-sungguh melakukan pekerjaannya dan memberikan usaha maksimal untuk menyelesaikan tugasnya, sehingga cenderung akan berhasil. Orang yang merasa berhasil akan merasa puas dengan hasil kerjanya tersebut.

Hasil hipotesis 3 menunjukkan bahwa self-efficacy berpengaruh positif pada kinerja. Hal ini senada dengan hasil penelitian Wang dan Netemeyer (2002) yang menjelaskan self efficacy mempengaruhi kinerja para tenaga penjual dan proses belajar secara signifikan mempengaruhi self efficacy tenaga penjual. Self efficacy yang tinggi akan membuat karyawan lebih aktif bekerja, berupaya keras, mampu mengatasi situasi kerja yang sulit dan semakin kreatif dalam menyelesaikan pekerjaan (Kreitner dan Kinicki, 2004).

Dalam penelitian Kreitner dan Kinicki (2004) didapat hasil bahwa self efficacy selain mempengaruhi kepuasan kerja dan kinerja, juga mempengaruhi stres kerja. Namun dalam penelitian ini hipotesis 2 yang menyatakan self efficacy berpengaruh negatif terhadap stres kerja tidak terbukti. Ketidak konsistenan hasil dalam penelitian ini dengan penelitian terdahulu disebabkan beberapa hal. Stress dipengaruhi oleh banyak faktor. Pertama, stress

dipengaruhi oleh karakteristik individu. Tenaga penjual jasa mungkin menghadapi sumber stress yang sama namun memiliki tingkat stress yang berbeda. Hal ini terjadi karena perbedaan individu. Situasi yang sama mungkin dipersepsikan secara berbeda oleh individu yang berbeda. Setiap individu juga memiliki kemampuan yang berbeda dalam mengatasi situasi yang dianggap sebagai ancaman (Greenberg dan Baron, 2003). Perbedaan- 
perbedaan ini mungkin menjadi penyebab tidak signifikannya hubungan self efficacy dengan stres kerja tenaga penjual.

Kedua, pengalaman kerja menjadi faktor yang mempengaruhi tingkat stres tenaga penjual dalam bekerja. Dalam penelitian ini mayoritas tenaga penjual memiliki pengalaman kerja yang cukup lama, yaitu diatas 8 tahun. Pengalaman kerja membentuk kepercayaan diri

tenaga penjual dalam menyelesaikan pekerjaan dan menghadapi stressor. Hal ini sesuai dengan pernyataan Gist dan Mitchell (1992), yaitu ketika individu sudah mengerjakan suatu pekerjaan secara berulang-ulang dan dalam waktu yang lama, maka secara otomatis akan meningkatkan self efficacynya.

Ketiga, perbedaan persepsi mengenai stres. Persepsi individu mengenai stres adalah hasil evaluasi kognitifnya mengenai kondisi yang dihadapinya (Greenberg dan Baron, 2003). Otonomi kerja membentuk faktor yang sangat penting dalam mempengaruhi perilaku tenaga penjual, yaitu self efficacy. Dengan bentukan self efficacy (self efficacy tinggi), maka individu lebih mampu mengatasi hambatan yang dihadapi. Hal ini mengubah persepsi tenaga penjual mengenai stres. Tenaga penjual tidak lagi mempersepsikan stressor sebagai ancaman dalam pekerjaan melainkan sebagai sesuatu yang membangun. Perubahan persepsi ini mungkin menjadi penyebab tidak signifikannya peran mediasi stres kerja pada hubungan self efficacy dengan kinerja (hipotesis 7).

Hasilhipotesis4menunjukkanbahwa kepuasankerjaberpengaruh positif pada kinerja. Tenaga penjual yang puas akan mengerjakan pekerjaannya sebaik mungkin dan akan meningkatkan kinerja. Hasil ini mendukung pola pertama dari tiga kemungkinan pola hubungan kepuasan kerja dengan kinerja, yaitu karyawan yang puas adalah karyawan yang efektif dan berkinerja baik. Temuan ini juga mendukung penelitian Engko (2006) dan hasil meta analisis yang dilakukan Petty et al. (1984) yang menemukan bahwa pola hubungan pertama (kepuasan mempengaruhi kinerja) adalah hubungan yang lebih konsisten. Namun hasil penelitian ini kepuasan kerja tidak memediasi hubungan antara self efficacy dengan kinerja (hipotesis 6). Hal ini terjadi karena antara self efficacy dengan kinerja memiliki hubungan langsung yang lebih besar. Artinya bahwa tanpa individu merasa puas terhadap pekerjaannya, self efficacy sudah mampu mempengaruhi kinerja yang tinggi bagi individu tersebut.

Stress kerja memiliki peranan dalam membentuk dan mempengaruhi sikap karyawan, seperti komitmen organisasional, kepuasan kerja dan kinerja (Sager,1994). Oleh karena itu, dalam penelitian ini stress kerja diduga mempengaruhi kinerja secara negatif (hipotesis 5). Hasil penelitian ini menunjukkan bahwa stress kerja tidak berpengaruh pada kinerja tenaga penjual. Hasil ini berbeda dengan hasil penelitian Spector (1986) mengenai 
stress dan kinerja. Ketidakkonsistenan hasil ini mendukung hasil meta analisis LePine et al. (2005) mengenai hubungan stress dan kinerja. LePine et al. (2005) menyatakan ketidak konsistenan hubungan stress dan kinerja terjadi karena pada kenyataannya stress kerja terdiri dari stress positif dan negatif. Stress positif (challenge stress) merupakan stress yang memberikan pengaruh positif karena menawarkan kesempatan bagi individu untuk mengembangkan diri. Stress negatif (hindrance stress) merupakan stress yang memberikan pengaruh negatif karena menghambat perkembangan dan tujuan pribadi. Oleh karena itu, LePine et al. (2005) menyarankan agar dalam penelitian tiap jenis stress diperlakukan dan diukur secara berbeda. Dalam penelitian ini stress hanya diperlakukan sebagai stress negatif (hindrance stress). Hal ini mungkin menyebabkan hubungan stres dan kinerja menjadi tidak signifikan.

\section{KESIMPULAN}

Penelitianinibertujuan untuk menjelaskan pengaruh selfefficacy terhadap kinerja dengan kepuasan kerja dan stres kerja sebagai variabel pemediasi. Penelitian ini juga bertujuan untuk menjelaskan pengaruh kepuasan kerja terhadap kinerja dan pengaruh stress kerja terhadap kinerja. Dari hasil penelitian dapat disimpulkan bahwa:

1. Self efficacy secara positif signifikan mempengaruhi kepuasan kerja dan kinerja. Selain itu kepuasan kerja juga secara positif signifikan mempengaruhi kinerja. Namun demikian peran kepuasan kerja dalam memediasi hubungan self efficacy dengan kinerja hanya bersifat parsial saja. Karena hubungan langsung antara self efficacy dengan kinerja lebih besar dibanding peran mediasi kepuasan kerja.

2. Self efficacy tidak secara signifikan mempengaruhi stres kerja, demikian juga stres kerja tidak secara signifikan mempengaruhi kinerja. Oleh karena itu peran mediasi stres kerja terhadap hubungan antara Selfefficacy dengan kinerja pun menjadi tidak terlihat. Perbedaan individu dan pengalaman kerja mungkin menjadi faktor-faktor yang menyebabkan tidak signifikannya hubungan kedua variabel ini.

\section{KETERBATASAN PENELITIAN}

Hasil penelitian ini mendukung tiga dari tujuh hipotesis yang dibangun. Namun penelitian ini masih memiliki beberapa keterbatasan yang terkait. Pertama,responden hanya berasal dari penyedia jasa asuransi saja. Hal ini akan berdampak pada validitas eksternal yang rendah. Namun peneliti sudah mengupayakan dengan mengumpulkan responden dari jasa asuransi yang berbeda-beda sehingga variasi ini diharapkan dapat meningkatkan validitas eksternalnya. Kedua, penilaian kinerja dilakukan sendiri oleh responden (self report). Hal ini tentu mengundang bias karena kemungkinan 
kinerja akan dinilai secara berlebihan. Sebelumnya peneliti sudah mencoba melakukan penilaian kinerja dengan multi rater, yaitu meminta supervisor untuk menilai kinerja bawahannya tetapi karena peneliti menemukan kecurangan (supervisor meminta bawahan mengisi sendiri) maka peneliti memutuskan untuk meminta tenaga penjual menilai kinerjanya sendiri. Ketiga, stres kerja tidak dibedakan menjadi stress positif dan negatif. Penelitian ini hanya menggunakan satu pengukuran, yaitu stres negatif sehingga tidak dapat menangkap fenomena stres positif pada tenaga penjual. Walaupun demikian, sebelumnya peneliti sudah melakukan wawancara dengan supervisor, area sales manager dan beberapa responden sehingga informasi mengenai stress kerja yang dialami juga dapat diperoleh.

\section{SARAN}

Berdasarkan beberapa keterbatasan penelitian tersebut, maka peneliti menyarankan beberapa hal untuk dilakukan pada penelitian yang akan datang. Pertama, penelitian selanjutnya diharapkan menggunakan responden dari beberapa industri jasa yang berbeda, misalnya perhotelan atau perbankan. Dengan menggunakan responden dari beberapa industri jasa yang berbeda diharapkan mampu meningkatkan validitas ekternal dari model yang diusulkan. Kedua, menggunakan multi rater atau menggunakan penilaian objektif (dari data

perusahaan) dalam menilai kinerja. Penilaian dengan menggunakan multi rater atau berdasarkan data dari perusahaan diharapkan dapat memberikan hasil yang lebih akurat. Ketiga, menggunakan instrumen stress kerja yang membedakan stress kerja positif dan negatif.

\section{DAFTAR PUSTAKA}

Brown, Steven, Shankar Ganesan, Goutam Challagalla;2001, "Self-Efficacy as a Moderator $\mathrm{f} \quad$ Information-Seeking Effectiveness," Journal of Applied Psychology, Vol.86, no. 5, al 1043-1051.

Bandura,Albert,1997, "Self-efficacy:The Exercise of Control", W.H.Freeman, New York.

Cohrs, J. Christopher; Abele, Andrea E. \& Dette, Dorothea E. (2006). Integrating Situational

and Dispositional Determinants of Job Satisfaction: Findings From Three Samples of professionals. The Journal of Psychology. Vol. 140, No. 4, pg 363-395.

Churchill, Gilbert; Ford, Neil M.; Hartley, Steven W. \& Walker, Orville C. (1985). The Determinants of Salesperson Performance: A Meta Analysis. Journal of Marketing Research. Vol. 22, pg. 103 
Denton, David W. \& Lawrence S. Kleiman (2001). Job Tenure as a Moderator of The Relationship Between Autonomy and Satisfaction. Applied H.R.M. Research. Vol. 21, No. 2, pg. 105-114.

Dormann, Christian \& Zaft, Dieter (2001). Job Satisfaction: a Meta-analysis of Stabilities. Journal of Organizational Behavior, Vol.22, pg. 483-504

Elsass, Priscilla M. \& Veiga, John F. (1997). Job Control and Job Strain: A Test of Three Models. Journal of Occupational Health Psychology. Vol. 2, No. 3, pg. 195-211

Engko, Cecilia (2006). Pengaruh Kepuasan Kerja TerhadapKinerja Individual Dengan Self-esteem dan Self-Efficacy sebagai Variabel Intervening. Simposium Nasional Akuntansi Padang. K-AMEN 06.

Gellatly, Ian R. \& Irving P., Gregory (2001). Personality, Autonomy and Contextual Performance for Managers. Human Performance, Vol.43, No.3, pg. 231-245

Gibson; Ivancevich; Donnelly; \& Konopaske (2004). Organizational Behavior, Structure, Processes. 11th edition. McGraw Hill Companies, Inc.

Gist, Marilyn E., \& Terence R. Mitchell. (1992). Self-efficacy: A Theoritical Analysis of Its Determinants and Malleability. Academy of Management Review. Vol. 17, No.2, pg. 183-211.

Greenberg, Jerald \& Baron, Robert A. (2003). Behavior in Organization. 8th edition.Pearson Educational, Inc., Upper Saddle.

Hair, J. F. Jr.; Anderson, R.E.; Tatham, R.L. \& Black, W.C. (2006). Multivariate Data Analysis, 6th edition. UpperSaddle River, Prentice Hall International, Inc.

LePine, Jeffery; Podsakoff, Nathan \& LePine, Marcie. (2005). A Meta Analytic Test of The Challenge Stressor-Hindrance Stressors Framework: An Explanation For Inconsistent Relationships Among Stressors and Performance. Academy of Management Journal. Vol. 48, No. 5, pg. 764-775.

McShane, Steven L., \& Von GLinow, Mary Ann. (2003). Organizational Behavior:Emerging Realities for The Workplace Revolution. 2nd edition. McGraw HillCompanies, Inc.

Miao, C. Fred; Evans, Kenneth R. \& Zou, Shaoming. (2007). The Role of Salesperson Motivation in Sales Control Sysytem-Intrinsic and Extrinsic Motivation Revisted. Journal of Business Research. Vol. 60, pg. 417-425.

Narayanan, Lakshmi; Menon, Shanker \& Spector, Paul E. (1999). Stress in the Workplace: A Comparison of Gender and Occupations. Journal of Organizational Behavior. Vol. 20, No. 1, pg. 63-73

Nguyen, Anh Ngoc., Jim Taylor \& Steve Bradley. (2003). Job Autonomy and Job Satisfaction: A New Evidence. Working Paper. 
Petty, M.,M., Gail, W. McGee \& Jerry W. Cavender (1984). A Meta Analysis of The Relationship Between Individual Job Satisfaction and Individual Performance. Academy of Management Review. Vol. 9, No. 4, pg. 712-721.

Saragih, Susanti, R (20070. Pengaruh Otonomi Kerja Terhadap Work Outcomes: Self efficacy sebagai Variabel Pemediasian, Yogyakarta

Wang, Guangping \& Netemeyer, Richard (2002). The Effects of Job Autonomy, Customer Demandingness, and Trait Competitiveness on Salesperson Learning,Self efficacy and Performance. Journal of The Academy of Marketing Science. Vol. 30, No.3, pg. 217-228. 